Jennie Billot, AUCKLAND UNIVERSITY OF TECHNOLOGY, jbillot@aut.ac.nz

Susan Rowland, UNIVERSITY OF QUEENSLAND, s.rowland1@uq.edu.au

Brent Carnell, UNIVERSITY COLLEGELONDON, b.carnell@ucl.ac.uk

Cheryl Amundsen, SIMON FRASER UNIVERSITY, camundsa@sfu.ca

Tamela Evans, GEORGIA SOUTHERN UNIVERSITY,

tamela_1_evans@georgiasouthern.edu

\title{
How Experienced SoTL Researchers Develop the Credibility of Their Work
}

\begin{abstract}
Teaching and learning research in higher education, often referred to as the Scholarship of Teaching and Learning (SoTL), is still relatively novel in many academic contexts compared to the mainstay of disciplinary research. One indication of this is the challenges those who engage in SoTL report in terms of how this work is valued or considered credible amongst disciplinary colleagues and in the face of institutional policies and practices. This paper moves beyond the literature that describes these specific challenges to investigate how 23 experienced SoTL researchers from five different countries understood the notion of credibility in relationship to their SoTL research and how they went about developing credibility for their work. Semistructured interviews were facilitated and analyzed using inductive analysis. Findings indicate that notions of credibility encompassed putting SoTL research into action and building capacity and community around research findings, as well as gaining external validation through traditional indicators such as publishing. SoTL researchers reported a variety of strategies and approaches they were using, both formal and informal, to develop credibility for their work. The direct focus of this paper on credibility of SoTL work as perceived by experienced SoTL researchers, and how they go about developing credibility, is a distinct contribution to the discussions about the valuing of SoTL work.
\end{abstract}

\section{KEYWORDS}

credibility of SoTL research, valuing of SoTL research, SoTL researchers

While there is much literature that focuses on how Scholarship of Teaching and Learning (SoTL) research informs teaching practice (c.f. Hutchings, Huber, \& Ciccone, 2011; Trigwell, Martin, Benjamin, \& Prosser, 2000), less attention has been directed to how researchers develop credibility for this work. A previous International Collaborative Writing Group (ICWG) supported by the International Society for the Scholarship of Teaching and Learning (ISSOTL) focused on SoTL researchers' identity development, including challenging questions about the credibility of their work (Simmons, Abrahamson, Deshler, Kensington-Miller, Manarin, Morón-García, Oliver, \& Renc-Roe, 2013). Our group used this ICWG paper, as well as the broader literature, as a jumping-off point for our research. We wanted to move beyond a description of the challenges surrounding credibility to develop a better understanding of what constitutes credibility for SoTL researchers and how they personally go 
about developing credibility (c.f. Hutchings \& Shulman, 1999; Weimer, 2008). Existing literature highlights the notion that credibility is an elusive factor since it cannot be universally defined (Nordhagen, Calverley, Foulds, O’Keefe, \& Wang, 2014) and can be viewed from a number of perspectives that are influenced by attitudinal beliefs and structural factors (McKinney, 2006). How one defines credibility therefore depends on perceptions of self and of one's work in relation to perceived expectations, both personal and structural. Such expectations "shape how individuals define credibility, a fundamentally relative concept” (Nordhagen et al., 2014, p. 159; emphasis in the original).

Through an exploratory study involving 23 experienced SoTL researchers, we aimed to gain insight into how individuals understood credibility and how they developed credibility for their SoTL work and for themselves as SoTL researchers. We employed a qualitative and holistic approach (Denzin \& Lincoln, 2013) to develop an understanding of the experiences and perspectives of the participants themselves.

\section{BACKGROUND}

Although there is a solid body of knowledge on how teachers experience higher education teaching, there is minimal literature that focuses on how researchers, in general, understand being a researcher. Åkerlind's (2008a) empirical study about the experience of being a disciplinary researcher noted that while researchers recognize the structural requirement to undertake research, their motivation is based more on the personal satisfaction they gain through doing research. Similarly, according to Stevens (2001), many researchers undertake research because it emerges from their own interests or concerns. Åkerlind (2008a) further claimed that researchers tend to focus on the impact of their research, not only for the field itself, but for "their standing within it" (p. 26), publishing in part to gain a reputation amongst their disciplinary peers. Thus, Åkerlind (2008b) argued, researchers aim to achieve both an "internal sense of competence and success" and an "external recognition" (p. 246). Of course, researchers are also influenced by increasing institutional demands for accountability, especially through externally driven assessment regimes, which are more pronounced in some countries than others. Sometimes this results in tensions between personal interest, extending one's own reputation, contributing to the scholarly field, and responding to external or institutional criteria. We argue that Åkerlind's characterization also fits SoTL researchers well, with the added proviso that personal satisfaction is often derived from directly influencing teaching and learning.

The difficulties that SoTL researchers face exist at several levels and have been well documented in the literature. These include individual challenges, such as having to learn new research methods most commonly used for SoTL research, but possibly different from those associated with one's discipline (Kelly, Nesbit, \& Oliver, 2012). This situation often brings into play attitudes and beliefs about what constitutes methodological rigor (McKinney, 2006; Trigwell et al., 2000). Further, SoTL researchers often face the added challenge of how their work is valued by colleagues, their institution, and their disciplinary field (Bass, 1999). Beyond the institutional level, SoTL researchers can face difficulties related to traditional and non-traditional indicators of external credibility (Masika, Wisker, \& Canning, 2016) and, in particular, finding appropriate and valued outlets for SoTL work (Witman \& Richlin, 2007).

Individuals who investigate teaching and learning may choose to engage with this work as their primary research endeavor or alongside their disciplinary research. For those disciplinary researchers who regularly contribute to a coherent and well-developed field of study, there may well be surprise at the diversity of individuals engaged in SoTL research, the breadth of the work, and what is sometimes perceived as a disparate focus. Identifying with and aligning with SoTL colleagues, even those 
investigating aspects of teaching and learning in the same discipline, may not be as easy as aligning with a more tightly focused disciplinary research community (Kelley, 2008).

Bush, Pelaez, Rudd, Stevens, Tanner, and Williams $(2013 ; 2015)$ identified that in science at least, a significant proportion of academics who undertake SoTL feel there is often a misalignment between the expectations of their employers and their own goals for undertaking SoTL research. Additionally, their employers frequently "misunderstand the nature of scholarly activity" that is SoTL in the science classroom (Bauer, Clevenger, Cole, Jones, Kelter, Oliver-Hoyo, \& Sawrey, 2008, p. 900). There is a persistent theme in the literature that SoTL is a "hard sell" regardless of context (Boshier, 2009 , p. 2). The fact that many institutions do not recognize or value SoTL research can also position SoTL scholars as 'outliers' to the general research context. This is especially disconcerting for those who focus only on SoTL research.

Negotiating institutional-level demands for productivity and criteria for career advancement can be challenging for those who choose to research teaching and learning since these role requirements are typically "weighted toward traditional research" (Walker, Baepler, \& Cohen, 2008, p. 183). In an evaluation survey of a SoTL mentoring programme, Michael, Case, Hill, Lochbaum, McEnery, and Perkins (2010) identified this particular challenge. At the same time, ambiguity and lack of shared meaning contribute to differences in perceptions and standards when evaluating SoTL work. Cashmore, Cane, and Cane (2013) found that, in some cases, education-based evaluative research is considered to be for internal consumption only, rather than being 'real' research (p. 28). When SoTL is undervalued or deemed peripheral, it impacts not only individual careers but also the degree to which SoTL findings influence teaching practice within the institution. As McKinney (2006) pointed out, higher education institutions vary in their capacity and willingness to integrate SoTL research and recognize its value for teaching both within and across disciplines.

SoTL scholars must make decisions about where to present and publish their work, taking into consideration how to best target the audience they want, but also how their choice will be valued in their institutional context. Distressingly, Weimer (2008) noted that however SoTL is positioned, published SoTL studies are poorly read and cited, and leading SoTL journals generally have low impact factors in comparison to leading journals in disciplines such as science.

These contextual and structural challenges at the level of the individual SoTL researcher, the institutional level, and beyond may give academics pause if they decide to engage in SoTL research. In this study, we investigate ways in which experienced SoTL researchers constructively address the process of establishing credibility for SoTL.

\section{RESEARCH DESIGN}

Our research question How do SoTL researchers define and experience developing credibility for their research? led us to use a qualitative design to explore participant perceptions and experiences through semi-structured interviews with 23 participants residing in Canada, New Zealand, Australia, United Kingdom, and the United States. Denzin and Lincoln (2013) support interviews as a way of achieving an outcome from the dialogue between researcher and participant, in this case, the participants' views on their SoTL research. The applicable ethical approvals were obtained from the researchers' institutions, and informed consent was obtained from each participant.

\section{Participants}

Table 1 shows the participants' demographics and pseudonyms. The majority of participants were female, and participants had on average just over 9 years of experience with SoTL and 16 years of 
teaching in higher education. Participants were recruited in two ways: some volunteered at the 2015 International Collaborative Working Group workshop in Melbourne, and others were identified at our own institutions using a snowballing process, through email, known contacts, and information notices about the study. Participation was limited to academics in higher education institutions with at least three years of experience in teaching and learning research. Participants also needed to work in a context where disciplinary research is clearly delineated from teaching and learning research.

Table 1. Roles, disciplines, and descriptive statistics for the study participants

\begin{tabular}{|c|c|c|c|c|c|c|}
\hline $\begin{array}{l}\text { PARTICIPANT } \\
\text { PSEUDONYM }\end{array}$ & GENDER & COUNTRY ${ }^{1}$ & $\begin{array}{l}\text { YEARS } \\
\text { IN HE }^{2}\end{array}$ & $\begin{array}{l}\text { YEARS OF T\&L } \\
\text { RESEARCH }\end{array}$ & UNIVERSITY ROLE ${ }^{4}$ & $\begin{array}{l}\text { ORIGINAL RESEARCH } \\
\text { DISCIPLINE }\end{array}$ \\
\hline Abigail & $\mathrm{F}$ & $\mathrm{NZ} \mathrm{A}$ & 30 & 11 & $\begin{array}{l}\text { Faculty, } \\
\text { Head of School }\end{array}$ & $\begin{array}{l}\text { Interprofess- } \\
\text { ionalism }\end{array}$ \\
\hline Apollo & $\mathrm{M}$ & US A & 18 & 18 & Tenured Faculty & Psychometrics \\
\hline Artemis & $\mathrm{F}$ & US B & 25 & 15 & $\begin{array}{l}\text { Centre for T\&L } \\
\text { Director }\end{array}$ & English \\
\hline Athena & $\mathrm{F}$ & US A & 7 & 7 & Faculty & Social Work \\
\hline Belinda & $\mathrm{F}$ & $\mathrm{NZ} \mathrm{A}$ & 15 & 3 & $\begin{array}{l}\text { Academic Equity } \\
\text { Director }\end{array}$ & $\begin{array}{l}\text { Health and } \\
\text { Environmental } \\
\text { Science }\end{array}$ \\
\hline Brisk & $\mathrm{F}$ & GB A & 28 & 20 & $\begin{array}{l}\text { Educational } \\
\text { Developer }\end{array}$ & Education \\
\hline Christine & $\mathrm{F}$ & NZ B & 7 & 7 & $\begin{array}{l}\text { Academic } \\
\text { Developer }\end{array}$ & Mathematics \\
\hline Daniel & $\mathrm{M}$ & $\mathrm{NZ} \mathrm{A}$ & 7 & 7 & Faculty & $\begin{array}{l}\text { Sport } \\
\text { Management }\end{array}$ \\
\hline Delight & $\mathrm{M}$ & US C & 13 & 10 & $\begin{array}{l}\text { Faculty, } \\
\text { SoTL Director }\end{array}$ & Philosophy \\
\hline Diana & $\mathrm{F}$ & AA A & 23 & 10 & T\&L Director & Social work \\
\hline Elegant & $\mathrm{F}$ & GB A & 20 & 15 & $\begin{array}{l}\text { Education } \\
\text { Development } \\
\text { Centre Director }\end{array}$ & Philosophy \\
\hline Eric & $\mathrm{M}$ & $\mathrm{NZ} \mathrm{A}$ & 12 & 3 & Not disclosed & Sports Sociology \\
\hline Holly & $\mathrm{F}$ & AU B & 9 & 4 & EF Faculty & Molecular Biology \\
\hline Lara & $\mathrm{F}$ & AU C & 8 & 8 & EF Faculty & Biology \\
\hline Legal & $\mathrm{M}$ & AU B & 13 & 7 & Research Fellow & Psychology \\
\hline Magic & $\mathrm{F}$ & CA A & 11 & 5 & $\begin{array}{l}\text { Faculty, } \\
\text { SoTL Associate } \\
\text { Director }\end{array}$ & $\begin{array}{l}\text { Culture and } \\
\text { Performance }\end{array}$ \\
\hline Melissa & $\mathrm{F}$ & CA B & 15 & 6 & EF Faculty & Physiology \\
\hline Mighty & $\mathrm{F}$ & AU D & 22 & 7 & EF Faculty & Biomedicine \\
\hline Monica & $\mathrm{F}$ & AU C & 16 & 8 & $\begin{array}{l}\text { Faculty, } \\
\text { Undergraduate } \\
\text { Program Director }\end{array}$ & $\begin{array}{l}\text { Nursing and } \\
\text { Midwifery }\end{array}$ \\
\hline Novel & $\mathrm{F}$ & GB A & 10 & 10 & Senior TF & Education \\
\hline
\end{tabular}


Table 1. Roles, disciplines, and descriptive statistics for the study participants (continued)

\begin{tabular}{l|l|l|r|r|l|l}
\hline $\begin{array}{l}\text { PARTICIPANT } \\
\text { PSEUDONYM }\end{array}$ & GENDER & COUNTRY & $\begin{array}{r}\text { YEARS } \\
\text { IN HE }^{2}\end{array}$ & $\begin{array}{r}\text { YEARS OF T\&L } \\
\text { RESEARCH }^{3}\end{array}$ & UNIVERSITY ROLE & $\begin{array}{l}\text { ORIGINAL RESEARCH } \\
\text { DISCIPLINE }\end{array}$ \\
\hline Rhythm & Pass & GB A & 15 & 7 & Principal TF & $\begin{array}{l}\text { Earth Science / } \\
\text { Education } \\
\text { Research }\end{array}$ \\
\hline Swift & F & US D & 22 & 12 & SoTL Director & $\begin{array}{l}\text { Behavioural and } \\
\text { Vision Science }\end{array}$ \\
\hline Tawny & F & GB A & 20 & 15 & Principal TF & Higher Education \\
\hline
\end{tabular}

1. ISO Country Codes: AU (Australia), CA (Canada), GB (Great Britain, but England for all participants), NZ (New Zealand), US (United States of America). Designations A-D indicate different universities (not a ranking).

2. Average years in Higher Education $=15.9 \pm 6.8$

3. Average years in SoTL $=9.3 \pm 4.6$

4. Abbreviations: T\&L (Teaching and Learning), EF (Education Focused), SoTL (Scholarship of Teaching and Learning), TF (Teaching Fellow)

\section{Data collection}

The interviews included four core questions and six demographic questions, though this paper draws on only two of the core questions. Participants were asked to explain what 'credibility' in teaching and learning research meant to them and were asked: "What are you personally doing to develop credibility around your teaching and learning research?" Participants were encouraged to focus on their own experiences. During pilot interviews conducted at the ICWG meeting, it became clear that greater probing was needed, so we added additional questions around how SoTL expertise was developed and the mechanisms used for establishing credibility with particular stakeholders. These additional questions were used for all 23 data-yielding interviews.

\section{Data analysis}

Interviews were transcribed and then coded by two of the researchers, using NVivo software, an inductive qualitative analysis procedure (Boyatzis, 1998), and the five phases recommended by Braun and Clarke (2006). A coding framework was developed around the following four research questions:

1. What is 'credibility' from the perspective of the SoTL researcher?

2. What are the activities and strategies that researchers do and use to establish credibility?

3. Why do researchers conduct SoTL?

4. What are the barriers and problems associated with establishing credibility for SoTL?

Themes and groups of nodes were created as required for each research question. The second researcher separately re-coded the entire dataset using the original coding framework, adding to it where appropriate. Any discrepancies between the two coders were discussed until a $100 \%$ inter-rater agreement was reached. Given the quantity of data and the word limit for this paper, we chose to focus the paper on questions one and two identified above.

\section{FINDINGS AND DISCUSSION}

This section probes participant responses around their understanding of credibility for teaching and learning research. In doing so, we show the links between individual SoTL researchers and their 
understanding of the value, both realized and potential, of the work they do. The participants' pseudonyms are used.

\section{Reasons for doing SoTL}

Unlike disciplinary research where research findings may or may not directly contribute to practice, SoTL research emerges from practice and is meant to directly inform it (McKinney, 2005; Prince, Felder, \& Brent, 2007). As one study participant commented, "My aim in doing [SoTL] research is not just to publish an article, it's actually to move practice forward' (Tawny). Participants indicated their formal job expectations around SoTL varied and were not always clearly defined (see Table 1). Some individuals held academic positions with formal expectations for SoTL research. Others were employed to support faculty in conducting SoTL research and also engage in SoTL themselves. A final configuration was those with traditional academic positions requiring disciplinary research who also engaged in SoTL research out of personal interest. Regardless of formal requirements or expectations, all of those we interviewed had clearly thought about SoTL from the perspective of credibility and could describe specific ways to develop credibility of this work and how they intended to pursue this in the future.

\section{The meaning of credibility}

When we set out to investigate how experienced SoTL researchers went about establishing and developing credibility for their work, we realized that we first had to establish what credibility in teaching and learning research meant to each individual. Some challenged the term and said that we instead should be using the word 'legitimacy' (why the research should happen) or 'buy-in,' reflecting their particular take on the notion of credibility. Table 2 provides the detailed coded participant responses.

In line with Åkerlind's (2008b) work with disciplinary researchers, the study participants referred to the meaning of credibility with reference to the perspectives of others or external validators, such as publication of work. There was also reference to credibility as an internal process of valuing. The internal sense and external sense of valuing, as Åkerlind (2008b) refers to it, were not easily teased apart in our data.

As might be expected, publication and citations were commonly mentioned as indicators of credibility (Felten, 2013; Hutchings \& Shulman, 1999), although a few participants questioned the value of publication in SoTL journals. Also mentioned were signs that the research was valued within the individual's institution, especially in processes involving career advancement (Masika, Wisker, \& Canning, 2016).

Multiple individuals considered credibility as putting SoTL research into action and building capacity and community around research findings. Consistent with this, individuals spoke of credibility in terms of moving beyond individual SoTL projects to provide solid research about learning and teaching. Brisk explained it in this way:

the work has to have some kind of impact. I think that's the value of working within the departments. If you initiate something and they take it on board and you can evaluate it, and then they develop it ... I'd like to think that I'm not just publishing, but the work is also having an impact. 
Community building as the basis of credibility was also reflected in perspectives about the importance of mentoring and engaging others in SoTL, essentially extending recognition for the work through the greater numbers of individuals involved. Athena spoke about her own reflections:

The other thing about credibility would be replicability. Can I take what I'm learning in my classroom and deliver it to someone else ... and they can use that knowledge to improve teaching in their own learning environment?

The reputation and expertise of the SoTL researcher was also seen as an aspect of creating credibility. Credibility was perceived as being stronger if the researcher engaged with the greater scholarly community, produced research that looked like quality disciplinary research, obtained research funding, and disseminated to both disciplinary and SoTL communities. Traditional or typical contributions to a scholarly community, such as examining theses, supervising students, presenting at conferences, and receiving invitations to speak about one's research, were perceived as important in establishing credibility for SoTL researchers. There was also a strong belief that the person doing the SoTL research needed to be perceived as a good and experienced teacher. Table 2 provides a more complete picture of the ways in which participants described credibility.

Table 2. Participant responses to the questions, "what does credibility in SoTL mean to you?" and "what are the indicators of credibility in SoTL?"

\begin{tabular}{l|l}
\hline RESPONSES & NUMBER OF MENTIONS \\
\hline $\begin{array}{l}\text { Scholarly activities that mirror academic disciplines } \\
\text { (detailed coding relating to publication appears in its own category below) }\end{array}$ & 107 \\
\hline Quality methods/approaches/rigorous research & 29 \\
\hline Conference/workshop presentations & 22 \\
\hline Work grounded in the field/literature & 11 \\
\hline Engagement with scholarly community & 10 \\
\hline Funding obtained & 10 \\
\hline Speaking invitations & 8 \\
\hline Collaborators & 5 \\
\hline Work cited by others & 3 \\
\hline Developing/discovering something new & 3 \\
\hline Journal editing/reviewing & 2 \\
\hline Examining theses & 1 \\
\hline Own results mirror literature & 1 \\
\hline Supervising students & 1 \\
\hline Book writing & 1 \\
\hline Capacity- and community-building activity & 94 \\
\hline Impact beyond the project/work creates cultural change & 25 \\
\hline Helping students/working with students as partners & 22 \\
\hline Work valued by the university/linked to university agenda & 13 \\
\hline Colleagues work with me to improve their T\&L practice & 12 \\
\hline
\end{tabular}




\begin{tabular}{l|l}
\hline Appointment to academic leadership position & 7 \\
\hline Current/prior disciplinary research output & 6 \\
\hline Mentoring/engaging others in SoTL & 3 \\
\hline Providing solid information about T\&L practice to stakeholders & 2 \\
\hline Work valued by the international community & 2 \\
\hline Work is published & 52 \\
\hline Publication valuable for credibility & 44 \\
\hline Publication not valuable for credibility/low impact factors problematic & 8 \\
\hline External validations & 36 \\
\hline Recognition from others (including disciplinary colleagues) & 23 \\
\hline Awards/fellowships for T\&L & 6 \\
\hline Work professionally rewarded by university & 6 \\
\hline Getting/having qualifications in SoTL & 1 \\
\hline Scholarly activities specific to SoTL & 7 \\
\hline Being a good/experienced teacher & 7 \\
\hline Internal validations & 5 \\
\hline Valuable/personally authentic to me (the researcher/teacher) & 5 \\
\hline
\end{tabular}

\section{Strategies to build SoTL credibility}

When participants were asked about the ways in which they developed credibility, they described strategies and activities they used to develop credibility for themselves as SoTL researchers as well as the credibility of the work itself. Table 3 lists the themes and subthemes extracted from the dataset for this question. We discuss some of these themes below.

\section{Table 3. Strategies and activities to develop credibility}

\begin{tabular}{l|l}
\hline & Attending conferences and meetings \\
& Through mentors and collaborators \\
LEVELOPING RESEARCH & PhD project \\
EXPERTISE & Postgraduate study (non-PhD) \\
& Reading and seeing the work of others \\
& Reviewing and editing \\
& SoTL Fellowship options \\
& Gaining a SoTL related Bachelor's degree \\
\hline INFORMATION SHARING & Bringing information into the university \\
& Feeding back to external stakeholders \\
& Feeding back to students \\
& Feeding back to university management \\
& Feeding back to help local colleagues \\
& Having a detailed professional website \\
& Identifying new audiences \\
Informing external community \\
Using social media
\end{tabular}




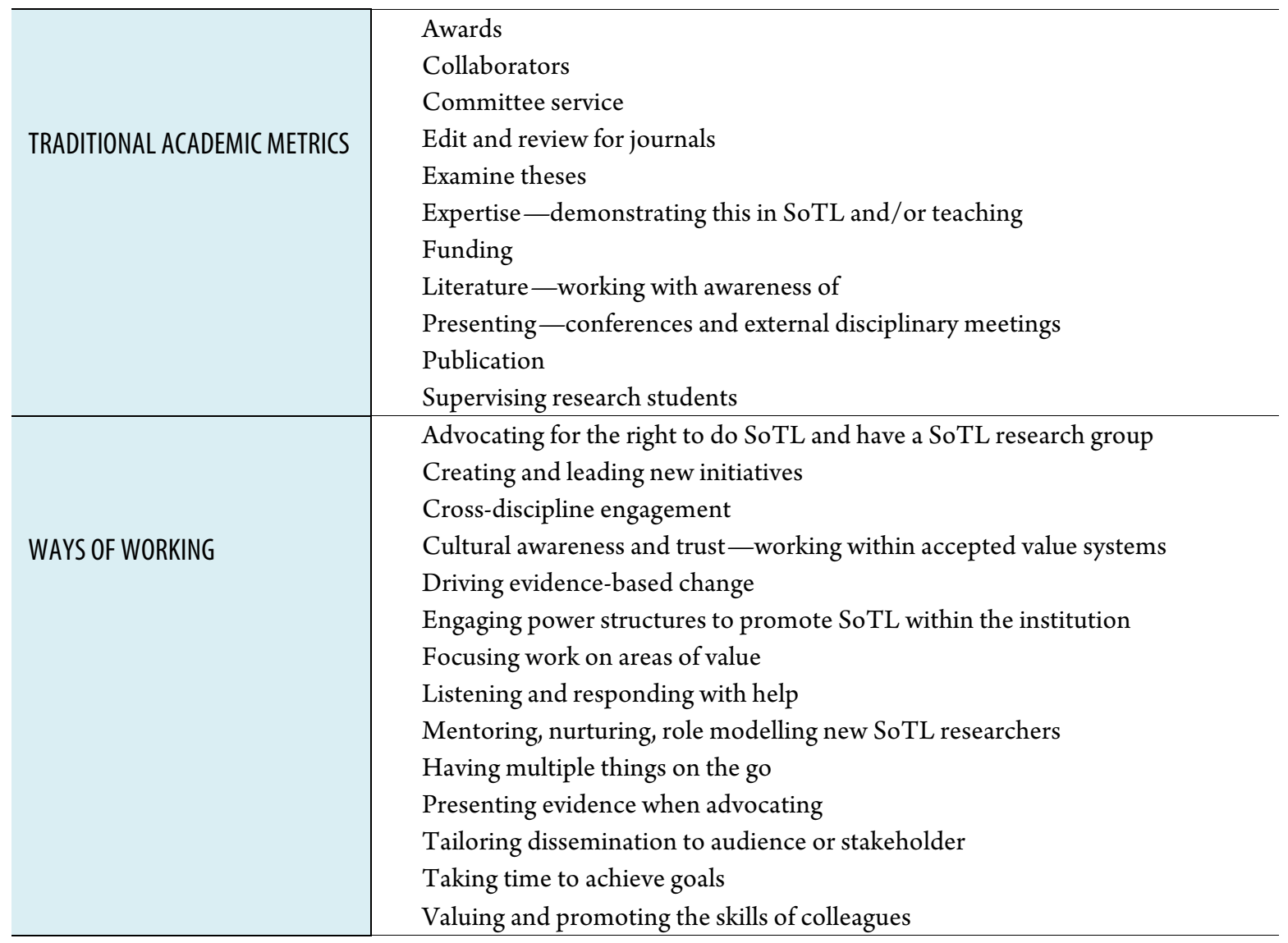

One strategy to develop credibility was to enhance research expertise specific to SoTL. Several of those interviewed came to SoTL work having conducted and published disciplinary research, and those particularly from the sciences and humanities had not anticipated how much they had to learn to develop expertise in the social science-oriented methods most commonly used in SoTL. They learned by doing and publishing, working with mentors and collaborators, and reading the work of others. Several spoke of attending conferences and meetings as a way to heighten their learning. A smaller number developed their expertise through their doctoral or post-doctoral research. Magic explained how she adjusted to a focus on SoTL:

\section{As I first started work in this field, I felt pretty strong pressure to learn somewhat foreign approaches and somehow I think part of showing that this work was credible and rigorous and up to snuff for me was being able to show that it aligned with some of those accepted methodologies that seemed very important to the field.}

Some of the participants in this study were in positions of power or authority at their institutions (e.g., Director of a Teaching and Learning Centre). These individuals (and others) frequently reported working strategically within the bounds of university policy and procedure to develop credibility for SoTL work. This required strategic thought of where best to put one's efforts within the institution and how to effect change in the face of traditional expectations of what constitutes valid research. One participant suggested that it was useful "when possible to attach your work to the institution's agendas" 
(Artemis). Another participant also focused on making SoTL research "useful for department programs . .. to show its value"(Swift). Diana found at least one "back door" to demonstrate the value of SoTL:

I was running a workshop on SoTL, so I asked our Deputy Vice Chancellor Research to come... I actually got [him] to engage with academics who were doing SoTL work... and pointed out that it [SoTL research] is category one research funding [a high-prestige class of competitive funding in Australia].

How SoTL researchers negotiated institutional requirements and expectations, while at the same time focusing on their research priorities, indicated both creativity and proactivity. Naturally, one of the formidable challenges that individuals faced was how their SoTL work was valued for promotion and tenure/permanence. Out of necessity, many interviewees had to advocate for SoTL work directly:

I went in to my Dean and said "I want you to know I've been a two-sport athlete for a while now"... And for me that's the best way to describe it, because I still publish in [my field] and I publish in SoTL. (Delight)

Apollo explained that in his position he was able to make decisions about career advancement and worked actively to promote the value of SoTL:

We have to explain it's not teaching, it's scholarship and if anybody on your (promotion and tenure) committee says it's teaching, they're ignorant and let's educate them.

Many participants described activities and strategies to create a broader value for SoTL work within their institutions and beyond. Sharing the findings of SoTL work with students and local colleagues through informal and formal activities was seen as important, especially the learning outcomes brought to light by this work. Most participants discussed the need to tailor messages for different stakeholders, providing ways to 'interpret' SoTL work. For example, helping institutional leaders grasp the broad significance of this work for the university's development was seen as important. Participants also emphasized work with external stakeholders and community members as important to highlight institutional successes and to serve as a model for other institutions.

When speaking with colleagues, both internal to their institution and external, individuals described the importance of connecting with disciplinary theories and frameworks:

I underpin it with that and I disseminate it in that way; I talk about it as "This research project that we did about learning analytics." You construct a dialogue around it so it makes sense. (Apollo)

I'm a structuralist from a social work point of view - so I look at structures and lobby to change them. Where I can, that's where I link things back to theory. When we talk about SoTL I'll say "Well, from a structural point of view..."-you use that language with them. (Diana)

Others inspired connection through the strength of their personal background and status as a disciplinary researcher: 
I came into this academic position as a biology researcher... I've been there and done that-I can talk the language ... I teach with them and one of the biggest things I've found in terms of ripple effects is that most of the colleagues in the school where I work will try something if a colleague has tried it first and has incidentally said "Hey, what about this? Have you thought about that?"(Lara)

when I came to the institution I was already a full professor, largely because of my disciplinary work. Stepping in, people say "Wow, she seems to be a credible person, and knows how to do quality work," and so that helped a lot. (Swift)

\section{Disseminating SoTL}

Participants talked about the importance of carefully choosing journals and conferences based on the intended audience, as well as on the value of the journal or conferences to one's immediate and disciplinary colleagues. A distinction was drawn between disciplinary journals that accepted papers about teaching and learning investigations, disciplinary journals in the field of teaching and learning, and SoTL journals. Similarly, a distinction was drawn between disciplinary conferences, higher education conferences, and industry conferences. Two participants explained how they addressed their planned journal submissions, while another explained the tension between presentation for impact and presentation for academic prestige amongst their disciplinary colleagues.

There are discipline-specific pedagogical journals and I publish in those, and so I let them know, which helps legitimize me, that not only am I publishing SoTL, but I'm publishing SoTL in a discipline-specific journal. (Athena)

I do try to balance between publishing in SoTL journals and publishing in higher education journals ... Largely because it's an important part of facilitating and fostering conversation between those two areas... So I think that's part of building credibility, not only for an individual researcher, but for the field [SoTL] more broadly. (Magic)

Here's the dilemma I struggle with, this university pressure to publish in these places (academic journals). I stood up recently to present my [SoTL] research ... to a group of CEOs from ... organizations all over New Zealand and I realized after that session they'd never heard of the research that we're doing here, even though I'd done most of that research embedded within their organizations. (Eric)

These themes provide much scope for further analysis. Primarily, this study aimed to explore credibility of and for SoTL research and, in particular, the ways in which experienced SoTL researchers had personally gone about developing credibility. We now discuss the implications of our findings as well as interesting and fruitful directions for future research.

\section{IMPLICATIONS AND CONCLUSION}

This study took us into the unchartered waters of researchers' perceptions of the notion of credibility related to their SoTL research and how they personally went about establishing credibility for this work. While there is research about researcher performativity and recognition, which Curtis (2008) warns risks subordinating research excellence, little has directly focused on how researchers conceive of 
the concept of credibility. As such, this paper introduces a more contestable domain where scholars choose how and what to prioritise and engage in, despite institutional and external pressures.

While credibility is a relative notion (Nordhagen et al., 2014), it became clear in this study that all participants perceived credibility as aligned with the value that their SoTL research offers to the learning community. The findings highlight that credibility for SoTL researchers may well differ from institutional and external indicators of credibility (McKinney, 2006; Walker, Baepler, \& Cohen, 2008). This differential provides multiple challenges for researchers since they need to address structural requirements while also trying to prioritise their own objectives.

It is significant that SoTL researchers, like disciplinary researchers, pursue their work primarily because they are motivated and committed to address something about which they feel strongly (Åkerlind, 2008a). The driving force for all of the participants in this study was a deep and personal commitment to improving student learning. As one participant remarked: "I think it's ultimately about student learning, so if it's to be credible it needs to at some point improve student learning. That's why we do it; I think that's why we should be doing it" (Delight).

This study identified that SoTL researchers have concerns about the assessment of their work both within their institutions and through external peer review processes. Inevitably, there will be comparisons between SoTL and disciplinary research. We were therefore not surprised that many of the credibility indicators that study participants identified for SoTL research mirrored the traditional indicators of value for disciplinary research. One participant did note a feeling of inauthenticity in her approach to researching: "I do also worry a little bit about trying too hard to just look like others" (Magic). Her comment resonated with that of Kreber (2013) concerning the relative importance of traditional indicators of credibility versus the importance of SoTL research to change and enhance teaching and learning practice. These competing priorities seemed to be a significant point of tension for our study participants, who reflected on how to allocate one's time between applying SoTL research findings and disseminating the work through traditional scholarly outlets.

Dissemination of SoTL research is another point of tension. More than one participant spoke about the confusion associated with choosing an appropriate vehicle for disseminating their work. They noted the need for credibility in the face of academic expectations, while also placing the research findings in the hands of those who could apply them. The choices are numerous compared to those available to most disciplinary researchers since there are disciplinary journals that publish articles about teaching and learning, journals focused on educational research generally, and journals specific to SoTL. The same variety is true for conferences. How SoTL researchers position their work with regard to these choices affects how the work is perceived by those within the institution and beyond. The fact that participants spoke about the differences in the way the same work was valued by different stakeholders indicates that SoTL scholars feel they are sometimes caught between their disciplinary community, the SoTL community, and other stakeholders who will interpret and value their work in different ways.

What impressed and intrigued us was how creatively the participants in this study addressed the complexity of doing and positioning SoTL research and the comprehensive approach necessary to achieve their aims. Their intention was to further the foundational goal of SoTL_improving teaching and learning - and to help others understand the value of this work. As Stevens (2001) noted, "achieving legitimacy depends not only on your goals but also on how you inspire trust and enthusiasm" (p. 70). Participants in this study heartily embraced this maxim.

While admittedly exploratory, this study has provided insight into how SoTL researchers address issues of credibility. Despite the challenges, participants demonstrated that there are concrete ways to be proactive and further the overall agenda of SoTL and, most importantly, the credibility and 
status of those who do this work and the work itself. Future research could more deeply explore the application of strategies identified in this study to develop credibility. Practically, the strategies already identified in this study could be used as a basis of an 'action plan' for other SoTL researchers.

\section{ACKNOWLEDGEMENTS}

We would like to acknowledge the early contributions of Anthony Baker of La Trobe University, Melbourne, Australia. The group would also like to acknowledge the participants who kindly shared their time and experiences.

We would also like to acknowledge the opportunity to work with the 2015 International Collaborative Writing Group and for their helpful discussions and fellowship.

Jennie Billot is an Associate Professor and Head of Researcher Development at the Auckland University of Technology, New Zealand.

Susan Rowland is an Associate Professor of Higher Education in the Institute of Teaching and Learning Innovation and the School of Chemistry and Molecular Biosciences at the University of Queensland, Australia.

Brent Carnell is a Senior Teaching Fellow at both The Centre for Advancing Learning and Teaching and The Bartlett School of Architecture, University College London, UK.

Cheryl Amundsen is a Professor in the Faculty of Education and Director, Institute for the Study of Teaching and Learning in the Disciplines, Simon Fraser University, Canada.

Tamela Evans is a doctoral candidate in Educational Leadership, Higher Education at Georgia Southern University, USA.

\section{REFERENCES}

Åkerlind, G. S. (2008a). An academic perspective on research and being a researcher: An integration of the literature. Studies in Higher Education, 33(1), 17-31.

Åkerlind, G. S. (2008b). Growing and developing as a university researcher. Higher Education, 55(2), 241254.

Bass, R. (1999). The scholarship of teaching: What's the problem. Inventio: Creative Thinking About Learning and Teaching, 1(1), 1-10.

Bauer, C. F., Clevenger, J. V., Cole, R. S., Jones, L. L., Kelter, P. B., Oliver-Hoyo, M. T., \& Sawrey, B. A. (2008). Hiring and promotion in Chemical Education, Journal of Chemical Education, 85, 898-901.

Boshier, R. (2009). Why is the scholarship of teaching and learning such a hard sell? Higher Education Research \& Development, 28(1), 1-15.

Boyatzis, R. (1998). Transforming qualitative information: Thematic analysis and code development. Thousand Oaks, CA: Sage.

Braun, V., \& Clarke, V. (2006). Using thematic analysis in psychology. Qualitative Research in Psychology, $3(2), 77-101$.

Bush, S. D., Pelaez, N. J., Rudd, J. A., Stevens, M. T., Tanner, K. D., \& Williams, K. S. (2013). Widespread distribution and unexpected variation among science faculty with education specialties (SFES) across the United States. Proceedings of the National Academy of Sciences, 110(18), 7170-7175.

Bush, S. D., Pelaez, N. J., Rudd, J. A., Stevens, M. T., Tanner, K. D., \& Williams, K. S. (2015). Misalignments: Challenges in cultivating science faculty with education specialties in your department. BioScience, 65(1), 81-89.

Cashmore, A., Cane, C., \& Cane, R. (2013). Rebalancing promotion in the HE sector: Is teaching excellence being rewarded. York: Higher Education Academy.

Curtis, B. (2008). The Performance-Based Research Fund: Research assessment and funding in New Zealand. Globalisation, Societies and Education, 6(2), 179-194. 
Denzin, N. K., \& Lincoln, Y. S. (2013). Collecting and interpreting qualitative materials (Eds.). Thousand Oaks: Sage. Felten, P. (2013). Principles of good practice in SoTL. Teaching \& Learning Inquiry: The ISSOTL Journal, 1(1), 121-125.

Hutchings, P., Huber, M., \& Ciccone, A. (2011). The scholarship of teaching and learning reconsidered: Institutional integration and impact. San Francisco, CA: Jossey-Bass.

Hutchings, P., \& Shulman, L. S. (1999). The scholarship of teaching: New elaborations, new developments. Change: The Magazine of Higher Learning, 31(5), 10-15.

Kelley, B. (2008). Trading zones: Building connections to past research in the scholarship of teaching and learning. InSight: A Journal of Scholarly Teaching, 3, 10-16.

Kelly, N., Nesbit, S., \& Oliver, C. (2012). A difficult journey: Transitioning from STEM to SOTL. International Journal for the Scholarship of Teaching and Learning, 6(1), 18.

Kreber, C. (2013). Authenticity in and through teaching in higher education: The transformative potential of the scholarship of teaching. London: Routledge.

Masika, R., Wisker, G., \& Canning, J. (2016). Defining and supporting the scholarship of teaching and learning (SoTL): A sector-wide study. SoTL case studies. York: Higher Education Academy.

McKinney, K. (2005). The value of SoTL in sociology: A response to "the scholarship of teaching and learning-done by sociologists: Let's make that the sociology of higher education." Teaching Sociology, 33(4), 417-419.

McKinney, K. (2006). Attitudinal and structural factors contributing to challenges in the work of the scholarship of teaching and learning. New Directions for Institutional Research, 2006(129), 3750.

Michael, R., Case, K. A., Hill, L., Lochbaum, J., McEnery, L., \& Perkins, K. (2010). Mentoring new scholars of teaching and learning: The national CASTL institute model. Transformative Dialogues: Teaching and Learning eJournal, 3(3), 1-15.

Nordhagen, S., Calverley, D., Foulds, C., O'Keefe, L., \& Wang, X. (2014). Climate change research and credibility: Balancing tensions across professional, personal, and public domains. Climatic Change, 125(2), 149-162.

Prince, M. J., Felder, R. M., \& Brent, R. (2007). Does faculty research improve undergraduate teaching? An analysis of existing and potential synergies. Journal of Engineering Education, 96(4), 283-294.

Simmons, N., Abrahamson, E., Deshler, J. M., Kensington-Miller, B., Manarin, K., Morón-García, S., Oliver, C., \& Renc-Roe, J. (2013). Conflicts and configurations in a liminal space: SoTL scholars' identity development. Teaching \& Learning Inquiry, 1(2), 9-21.

Stevens, S. (2001). Fieldwork as commitment. Geographical Review, 91(1-2), 66-73.

Trigwell, K., Martin, E., Benjamin, J., \& Prosser, M. (2000). Scholarship of teaching: A model. Higher Education Research and Development, 19(2), 155-168.

Walker, J. D., Baepler, P., \& Cohen, B. (2008). The scholarship of teaching and learning paradox: Results without rewards. College Teaching, 56(3), 183-189.

Weimer, M. (2008). Positioning scholarly work on teaching and learning. International Journal for the Scholarship of Teaching and Learning, 2(1), 4.

Witman, P. D., \& Richlin, L. (2007). The status of the scholarship of teaching and learning in the discipline. International Journal for the Scholarship of Teaching and Learning, 1(1), 14.

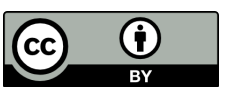

Copyright for the content of articles published in Teaching \& Learning Inquiry resides with the authors, and copyright for the publication layout resides with the journal. These copyright holders have agreed that this article should be available on open access under a Creative Commons Attribution License 4.0 International (https://creativecommons.org/licenses/by/4.0). The only constraint on reproduction and distribution, and the only role for copyright in this domain, should be to give authors control over the integrity of their work and the right to be properly acknowledged and cited, and to cite Teaching \& Learning Inquiry as the original place of publication. Readers are free to share these materials - as long as appropriate credit is given, a link to the license is provided, and any changes are indicated. 